\title{
EGÉSZ ÉLETEN ÁT TARTÓ TANULÁS, SZAKMAI FEJLŐDÉS A TANÁRI PÁLYÁN ${ }^{1}$
}

\section{A TEMPUS KÖZALAPÍTVÁNY KÖZREMÜKÖDÉSE AZ EURÓPAI GONDOLATOK TERJESZTÉSÉBEN}

\author{
SZEGEDI ESZTER \\ a Tempus Közalapítvány \\ munkatársa \\ http://www.tka.hu/
}

\begin{abstract}
Az Európai Unió oktatási és szakmai együttmüködéseket támogató „Egész életen át tartó tanulás programja” a tanulási célú együttmüködésekre és szakmai tanulási formákra kinál változatos pályázati lehetőségeket, mely programot Magyarországon a Tempus Közalapitvány koordinálja. A tanulási célú nemzetközi mobilitás elömozdítása prioritásként jelenik meg az Európai Bizottság munkaprogramjaiban, mivel az egyéni fejlödési lehetöségek mellett támogathatja az oktatási és képzési rendszerek és intézmények nyitottabbá, átláthatóbbá és hatékonyabbá tételét a tudásáramlás elömozdításával. A pedagógusoknak kulcsszerepe van a sikeresen megvalósuló mobilitási programokban, melyek során nem csak diákjaik számára nyílik a hagyományostól eltérő tanulási lehetőség, hanem saját maguk számára is. A cikkben bemutatjuk, hogy milyen európai mobilitási programok közül választhat egy tanár pályája különböző szakaszaiban, és milyen szakmai tudásra tehet szert általuk. Hogyan szolgálják a tanulási célú mobilitási programok a pedagógus életpálya egyes állomásain az egyéni fejlödési utat, valamint hogyan válhat a mobilitási programokban való aktív részvétel akár egy intézmény komplex pedagógiai eszközévé, oktatási stratégiájának részévé.
\end{abstract}

A Tempus Közalapítvány fő tevékenysége az Európai Unió oktatási és szakmai együttműködéseket támogató Egész életen át tartó tanulás programjába (Lifelong Learning Program - LLP) tartozó mobilitási pályázatok és egyéb szakmai tevékenységek koordinálása. A négy szektoriális alprogram a tanulási célú együttmüködésekre és szakmai tanulási formákra kínál változatos pályázati lehetőségeket az oktatás és képzés egy-egy területén. A Comenius program a közoktatásban nyújt támogatást óvodától az érettségi szintjéig, az Erasmus a felsőoktatási hallgatók és

\footnotetext{
${ }^{1}$ A szerző felhasználta a Tempus Közalapítvány további munkatársainak munkáit: $B$. Tier Noémi, Dimák Dávid, Hlavatý Ildikó, Jenei János, Kardos Anita, Kármán Tímea, Lukács Julianna, Révai Nóra.
} 
dolgozók tanulási célú mobilitására, a Leonardo a szakmai képzés összes szintjén és területén kínál lehetőségeket, végül a Grundtvig program a szakmától független felnőttkori tanulás számára biztosít forrásokat.

Az LLP program fent említett alprogramjai mellett az ún. transzverzális programokon keresztül ösztönözni kívánja a szektorokon átívelő együttmüködéseket is, valamint a tagállamok közti tudásmegosztást az oktatási és képzési rendszerek átláthatóságának és minőségének javítása érdekében. Ennek keretében a Tempus Közalapítvány a pályáztatáson túlmenően számos további szakmai feladatot lát el: közremüködés az európai szintű szakmapolitikai fejlesztések hazai megismertetésében, részvétel az európai integráció előmozdítását célzó nemzetközi együttmüködésekben az oktatás és képzés területén, információmegosztó szerep a nemzetközi szakirodalom és a bevált jó gyakorlatok összegyüjtésével és terjesztésével.

\section{A tanulási célú mobilitás}

A tanulási célú mobilitásnak már az ókorra, középkorra visszanyúló történelmi hagyományai vannak, de a szervezett keretek között zajló, központi források által támogatott formája az elmúlt néhány évtizedben került elötérbe Európában. Az 1990es években az Európai Unió egyre több olyan közösségi programot indított el, mely a fiatalok nemzetközi tapasztalatcseréjére alapozva kívánta támogatni a nyitott, toleráns, más kultúrára fogékony ifjúság nevelését (Youth, Socrates, Leonardo da Vinci). A 2000. évi Lisszaboni csúcstalálkozót követően felerősödött a nemzeti oktatáspolitikák közösségi összehangolása, ezzel együtt a mobilitást támogató programok felértékelődése is. Az oktatási miniszterek Tanácsában bevezették az ún. „gördülö napirendi pontokat”, melyek bármely elnökség ideje alatt napirendre kerülnek. E témák között szerepel a mobilitás és a végzettségek elismerése is, olyan további fókusztémák mellett, mint az oktatás a foglalkoztatáspolitikában és a minőség kérdése. 2006-ban Európai Mobilitásminőségi Chartát fogadtak el, 2007-től pedig megújult formában, még több finanszírozási forrást bevonva, a korábbi közösségi programok helyett elindították az Egész életen át tartó tanulás programját, melyben már megjelenik a tanulásról és oktatásról való újfajta gondolkodás, paradigmaváltás is.

2008 márciusában az Európai Tanács célul tüzte ki a tudás szabad áramlása elött álló akadályok felszámolását, az ún. ötödik szabadság megteremtésével, amely a kutatók, a hallgatók, a tudományos szakértők és az egyetemi oktatók határokon átnyúló mobilitásának növelését is magában foglalja. Ezt követte a 2008 novemberében elfogadott Tanácsi következtetések a fiatalok mobilitásáról kibocsátása, mely szerint „minden fiatal számára biztosítani kell annak lehetőségét, hogy a 
mobilitás valamilyen formájában részt vegyen, akár tanulmányai vagy képzései ${ }^{2}$ során, akár szakmai gyakorlat, akár önkéntes tevékenység keretében”. (Tanácsi következtetések a fiatalok mobilitásáról..., 2008, C 320/7)

$\mathrm{Az}$ egyre inkább a figyelem középpontjába kerülő tanulási célú nemzetközi mobilitás hatásait számos kutatási program is vizsgálta. Megállapításuk szerint a fiatalok a mobilitásban való részvételt szakmai és személyes fejlődésük egyaránt meghatározó állomásaként említik, $\mathrm{s}$ további előnyként tekintenek rá munkaerőpiaci elhelyezkedésük szempontjából is. Az új ismeretek megszerzése mellett kiemelt jelentőségű a nyelvi és interkulturális kompetenciák megalapozása vagy továbbfejlesztése, valamint az életben meghatározó szerepet játszó további képességek (kezdeményezőkészség, felelősségvállalás, tolerancia, problémamegoldás, konfliktuskezelés stb.) elsajátítása.

A 2008-as Tanácsi következtetések felhívta a tagállamok és az Európai Bizottság figyelmét arra is, hogy dolgozzanak ki közös európai, valamint önálló tagállami mobilitási koncepciókat az eredményesség érdekében. A bolognai folyamatban részt vevő országok felsőoktatási miniszterei által 2009. április 29-én elfogadott Leuveni Nyilatkozatban már konkrét célkitüzésként szerepel, hogy 2020-ra az európai felsőoktatási térség végzőseinek legalább 20 százaléka folytasson tanulmányokat vagy vegyen részt képzésben külföldön is. 2009 végén az Európai Bizottság nyilvános konzultációt kezdeményezett annak érdekében, hogy a tanulási célú mobilitás - ma még inkább kivételnek számító gyakorlata - rövid időn belül az összes európai fiatal számára elérhető, az európai lét természetes jellemzője legyen (Zöld könyv a fiatalok..., 2009). Az Oktatás és képzés 2020 stratégiai keret első stratégiai célkitüzése az egész életen át tartó tanulás és a mobilitás megvalósítása, és folyamatban van egy mobilitási referenciaérték (benchmark) kidolgozása is.

A tanulási mobilitásnak nem csak az egyéni fejlődésben van fontos szerepe, hanem az oktatási, képzési rendszerek és intézmények nyitottabbá, átláthatóbbá, hatékonyabbá, valamint könnyebben elérhetővé válásában is, hiszen előre mozdítja a tudás áramlását. Ezért a pályázati támogatások rendkívül változatos tanulási célú együttmüködésekre teremtenek lehetőséget: egyéni mobilitás oktatóknak vagy tanulóknak; partnerségek két vagy több különböző országban müködő oktatási in-

\footnotetext{
${ }^{2}$ Az Európai Unió szóhasználata megkülönbözteti az oktatás és a képzés fogalmát. Az oktatás (education) általában véve az ember személyes, értelmi és gondolkodási képességeinek fejlesztésére irányuló tevékenység. Ezzel szemben a képzés (training) valamely speciális tudás vagy képesség megszerzésére irányul, és közvetlenebb kapcsolatot feltételez az egyén foglalkoztathatóságával egy bizonyos szakmában. A tanulási tevékenység szintjére vagy formájára vonatkozóan nincs egyértelmüen meghatározható különbség a két fogalom között, de céljukban, történelmi gyökereikben és módszertanukban megfogalmazhatók konkrét különbségek. Az egész életen át tartó tanulás fogalma pedig az ember önkéntes, belső motivációra épülő, nem kizárólag munkaerő-piaci versenyelőny megszerzésére irányuló törekvését fejezi ki az élethosszig tartó önfejlesztésre. Beletartozik a szervezett keretek között zajló oktatási, képzési tevékenységekben való részvétel éppúgy, mint az informális és spontán tanulási folyamatok.
} 
tézmény között; többoldalú projektek nemzetközi együttmüködésben, ahol a hangsúly a projekt konkrét termékén van; tematikus szakmai hálózatok támogatása a bevált jó gyakorlatok megosztására és az eredmények terjesztésére; szakmapolitikai együttmüködések, innováció.

A tanulási mobilitás korábban említett pozitív hozadékai mellett alapvető fontosságú, hogy megfelelő módon lehessen elismertetni és érvényesíteni a külföldi tanulmányokat. Ezt a célt is szolgálja számos európai szinten bevezetett eszköz, mint a felsőoktatásban használt Európai Kreditátviteli Rendszer (ECTS), a 2009ben elfogadott Európai Szakképzési Kreditrendszer (ECVET), az Európai Képesítési Keretrendszer (EKKR) vagy az Europass dokumentumok.

\section{A pedagógusok szerepe a sikeres mobilitási programokban}

A sikeres tanulási mobilitásban kulcstényező a gondos előkészítés, és ebben kulcsszereplö lehet a felkészítő pedagógus. Szükség van körültekintő tájékoztatásra és tanácsadásra a rendelkezésre álló finanszírozási forrásokról, a választható tanulási lehetőségekről, oktatási programokról, de akár a gyakorlati kérdésekről, mint a lakhatás, megélhetési költségek stb. De ennél talán még fontosabb a fiatalok motiválása. A tapasztalat azt mutatja, hogy ahol több információhoz jutnak hozzá a fiatalok arról, hogy milyen előnyökkel járhat a külföldi tanulás, ott sokkal nagyobb arányban válnak nyitottabbá külföldi tanulmányok folytatására. Egy-egy lelkes tanár, szakoktató vagy ifjúságsegítő, aki maga is részt vett mobilitásban, fontos motiváló lehet a fiatalok számára. Ez ugyan nyilvánvalóan személyes erőfeszítést kíván a részükröl, ugyanakkor pozitív hatással lehet saját személyes szakmai fejlődésükre is.

A már említett Zöld könyv javaslatokat fogalmaz meg arra vonatkozóan, hogy ,az iskolai, egyetemi és szakképzésben tevékenykedő tanárok és oktatók, valamint az ifjúsági szervezetekben müködő ifjúságsegítők esetében a mobilitási időszakokat karrierfejlesztésük szerves részeként kellene ösztönözni és elismerni. Ehhez hasonlóan munkaköri leírásukban és munkatervükben megfelelően el kellene ismerni a tanárok, oktatók és ifjúságsegítők abba fektetett idejét és erőfeszítéseit, hogy fiatalokat segítenek külföldi tartózkodásukra felkészülni.” (Zöld könyv a fiatalok..., 2009. 19. o.)

Az alábbiakban bemutatjuk, hogy milyen európai mobilitási programok közül választhat egy tanár pályája különböző szakaszaiban, és milyen szakmai tudásra tehet szert az egyes programok kapcsán, valamint milyen saját tevékenységekkel támogatja a tanárok szakmai fejlödését a Tempus Közalapítvány az LLP programok mellett. 


\section{Középfokú oktatás: Comenius és Leonardo mobilitási programok, iskolai együttműködések}

Évröl-évre óvodák, általános iskolák, szakiskolák és gimnáziumok ezrei fognak össze szerte Európában azért, hogy egyenrangú partnerként együttmüködve közösen kidolgozzanak és eredményesen megvalósítsanak egy projektet. Ezekben a nemzetközi együttmüködésekben a közoktatási és szakképzési intézmények diákjai, tanárai, nevelöi, munkatársai folyamatosan tartják a kapcsolatot egymással, közösen dolgoznak a pályázatban vállalt feladatok teljesítésén, és a projekt részét képezi a partnerek személyes találkozója is. A Comenius programok keretében az iskolák közötti együttmüködés két teljes évig tarthat, melynek végére egy közös projekttermék születik meg. A Leonardo mobilitási program egyik legfontosabb hozadéka a megszokott hazai körülményektől eltérő közegben megvalósuló szakmai gyakorlat által elmélyülő motiváció és szakmaszeretet.

A projekt eredménye azonban nemcsak a közös projekttermék, vagy a szakmai tapasztalatszerzés, hanem számos további hozadéka is lehet a munkának az egyes résztvevők számára, melyet a tanítás, a tanulás vagy a hétköznapi élet más területén is hasznosítani tudnak. Olyan fejlődési lehetőség ez, melynek során a szakmai vagy projektmunka alapját képező tématerületen való jártasságon túl önkéntelenül is új képességekre tesznek szert mind a diákok, mind pedig a pedagógusok. Előtérbe kerül a csoportmunka, a társadalmi kapcsolatok, az együttmúködést igénylő tevékenységek tervezése és megvalósítása, és az eredményes megvalósításhoz számos más kulcskompetencia megléte is szükséges az idegen nyelvi kommunikáción túlmenően.

Az együttmüködés hozzásegíti az iskolákat nemzetközi kapcsolataik bővítéséhez, valamint olyan általános érvényű célok megvalósításához is hozzájárulhat, mint a tanári kar nyelvi, kommunikációs és IKT képességeinek és a tanulók nyelvtanulás iránti motivációjának erősítése, a projektmódszer meghonosítása az iskolában vagy a tantárgyközi ismeretek oktatásának előtérbe állítása.

A pályázati kiírásokban általában prioritásként jelennek meg az általában fejlesztésre szoruló iskolai feladatok, mint például a hátrányos helyzetủ vagy sajátos nevelési igényü tanulók integrálása, a tantárgyköziség vagy a minőségbiztosítás. Ezek közül kettőt külön is érdemes kiemelni: az interkulturális tanulást és a multikulturális nevelést. A kultúrák közötti párbeszéd különös jelentőséggel bír az oktatás területén, hiszen a ma tanárai sokat tehetnek a jövő generáció toleranciájának alakításáert, ha az iskolában is hangsúlyt helyeznek más kultúrák felfedezésére, megértésére és tiszteletben tartására. Az eltérő kultúrák, társadalmi csoportok iránti érzékenyítés, a különböző gondolkodásmódok értékként való elfogadása az EU bövítésével, a bevándorlók számának növekedésével hangsúlyosabbá vált, fontos kihívást jelent az eltérő kulturális hátterü gyermekek integrációjában, a diszkrimináció megszüntetésében. 
Az elmúlt években Magyarországon évente kb. 3000-en vesznek részt Comenius iskolai együttmüködésben vagy Leonardo mobilitásban mintegy 200 iskolából. Ez 5-600 tanárt jelent évente, akik beszámolóikban mindig érzékeltetik, hogy a projekt legnagyobb hozadéka saját szakmai fejlődésük volt. Nem elhanyagolható az a tényező sem, hogy az a diák, aki 10-18 évesen részt vesz nemzetközi együttmüködésben, az nagyobb valószínüséggel pályázik majd további tanulmányai során is hasonlóra. Optimista megközelítésben azt is gondolhatjuk, hogy akár a tanári pálya is vonzóbbá válhat számára a lehetőségek láttán.

\section{Mobilitási lehetőségek a tanárképzés során: Erasmus programok}

Magyarországon valamennyi tanár- és pedagógusképzést nyújtó felsőoktatási intézmény részt vesz az Erasmus programban, így hallgatóinak, oktatóinak és nem oktatói beosztásban dolgozó munkatársainak lehetöségük van arra, hogy rövidebbhosszabb külföldi szakmai úton bővítsék ismereteiket.

A felsőoktatási intézmények hallgatói tanulmányaik alatt egy- vagy kétszemeszteres külföldi csereféléven vagy szakmai gyakorlaton vehetnek részt. A külföldi félév alatt lehetőségük nyílik olyan kurzusok látogatására, amelyek nem szerepelnek a küldő intézményük kínálatában, így újfajta módszereket, megközelítéseket sajátíthatnak el.

Lehetőség van rövidebb ideig tartó nemzetközi kurzusra való jelentkezésre is. A legalább tíz napig tartó Erasmus Intenzív Programokat három különböző ország és minimum tíz külföldi hallgató részvételével szervezik meg a partnerek. Ezek a tömbösített kurzusok bármilyen szakterületen történő együttmüködésre lehetőséget adnak. 2009-ben nagy sikerü és igen színvonalas Erasmus Intenzív Programot koordinált a Károli Gáspár Református Egyetem a tanárképzés területén. A Törökországban megrendezett projekt során az elméleti előadások mellett a hallgatók iskolai tanórákat is látogattak, majd a számukra kijelölt mentor segítségével tanítottak. A legjobb oktatási anyagok a többi hallgató számára is elérhetők az egyetem Moodle felületén.

Évente kb. 200 tanárképzésben résztvevő diák nemzetközi tanulmányát támogatja az Erasmus program Magyarországon.

\section{A pályakezdő pedagógusok programja: Comenius tanárasszisztensi akció}

Ezzel a támogatási formával végzős vagy frissen végzett tanárok élhetnek, a 3-10 hónapos gyakorlat alatt külföldi környezetben, mentor tanár támogatásával próbálhatják ki frissen szerzett pedagógiai ismereteiket. A fogadó ország tanárasszisztensi megbízást kínál valamely közoktatási intézményében, ahol általában heti 12-16 órában foglalkoztatják a fiatalokat, bevonva őket az iskolai tevékenységek változatos formáiba. A tanárasszisztensi alprogram egyedülálló fejlődési lehetőséget kínál a 
leendő tanárok számára pedagógiai, nyelvi és kulturális kompetenciáinak bővítésére, módszertani és nyelvtudásuk gyakorlására, és a fogadó ország várhatóan eltérő oktatási rendszerének megismerésére. A támogatott tanárasszisztensek előzetes felkészülését támogatja az Erasmus programban szervezett Intenziv Nyelvi Kurzuson való részvételi lehetőség is.

Természetesen a fogadó intézmények számára is rendkívül hasznos lehet egy idegen anyanyelvü tanárasszisztens fogadása, amennyiben munkáját körültekintően készítik elő. Az intézmények erre a Comenius tanárasszisztens fogadása programban tudnak jelentkezni. A pályázatokon részt vevő iskolák többek között a diákok nyelvtanulási motivációjának erősödéséről, a kulturális különbözőségek iránti érzékenység és tolerancia növekedéséről, új módszertani eszközök meghonosodásáról számolnak be, mint az asszisztens fogadásának egész iskolára ható pozitív hozadékai. Emellett nyitott tanári kar számára mind egyéni, mind közösségi fejlődési lehetőséget kínál a programban való részvétel, mert nem csak a tanári kar nyelvi és kommunikációs készségei erősödhetnek, hanem önfejlesztési lehetőséget kínálnak a külső megfigyelő kérdései, észrevételei is. Kulcsfontosságú a mentor tanár szerepe, aki megfelelő tapasztalattal és empátiával segítheti az asszisztens első pedagógiai próbálkozásait, így tapasztalt tanárok számára is jelenthet kihívást a programban való részvétel.

Magyarországról évente kb. 40 diák megy külföldre a tanárasszisztensi program keretében, és több tucat iskola jelentkezik fogadó intézménynek.

\section{Lehetőségek aktív tanároknak: Comenius és Pestalozzi tanártovábbképzések, Leonardo mobilitás szakképzési szakembereknek}

A programok a közoktatásban és szakképzésben dolgozó, már gyakorlattal rendelkező pedagógusok számára nyújtanak külföldi továbbképzési lehetőségeket. A nemzetközi környezetben megvalósítandó tevékenységek színes palettájáról lehet választani: kurzusokon, konferenciákon, szemináriumokon való részvétel, hospitálás vagy job-shadowing tevékenység, szakmai tanulmányutak. A program elsődleges célja a pedagógusok, szakoktatók gyakorlatban alkalmazható szakmódszertani ismereteinek bővítése, motivációjuk növelése.

A programban résztvevő pedagógusok visszajelzése alapján a nemzetközi környezetben való tapasztalatszerzés mellett fontos hozadéka a továbbképzésnek a saját munkájukról való reflexió gyüjtése, a szakmai kapcsolatok kialakítása, további együttmüködések tervezése, valamint az általános nyelvi készségeken túl a szaknyelvi ismeretek bővülése is. A szakképzési szakemberek mobilitása során is különleges prioritást élvez a tanárok, trénerek és oktatók kompetenciáinak fejlesztése és a cégekkel, vállalatokkal való együttmüködés a kompetencia alapú, tanulási eredményeken alapuló pedagógiai szemléletmód kialakításában. A szakoktatók számára rendkívül inspiráló lehetőség a szakmai gyakorlaton való aktív részvétel, 
melynek során a hangsúly a szakmai ismeretek bővítésén van, hiszen saját gyakorlati tevékenységén keresztül nyílik lehetősége új technológiák megismerésére.

A Pestalozzi tanártovábbképzési program a demokrácia, az emberi jogok és a jogállamiság témáit érintő kurzusokat kínál. A továbbképzések célja, hogy a résztvevő pedagógusok segítséget kapjanak és nyújtsanak egymásnak abban, hogy a közös európai értékek hogyan jeleníthetők meg az oktatási gyakorlatban. Az adott témában már előzetes ismeretekkel rendelkező pedagógusok oszthatják meg egymással tapasztalataikat és közösen dolgozhatnak ki az iskolai közegben alkalmazható új megközelítéseket, tevékenységeket.

A szakmai továbbképzési programokon évente kb. 200 pedagógus vesz részt, túlnyomó többségük, kb. 90 százalékuk nyelvtanár, akik a nyelvtanítással kapcsolatos továbbképzésekre jelentkeznek. Az egyéb tantárgyak oktatóinak mobilitását előzetes nyelvtanfolyamon való részvételi lehetőségekkel is igyekszik a program motiválni. Ennél magasabb arányú a szakképzési intézmények oktatóinak csereprogramban, szakmai gyakorlaton, tanulmányi úton való részvétele. Az elmúlt években folyamatosan növekvő mobilitások számából jól látható, hogy a tanárok körében igény van a megújulásra. A szakképzési szakértők célcsoportjában évente kb. 30 mobilitási projektet fogad el a Közalapítvány, melyben 3-400 résztvevő az önképzés, az új iránti fogékonyság, a nyitottság, a szakszerüség jegyében vesz részt a mobilitási programokban.

A Tempus Közalapítvány a tanártovábbképzési kurzusokon résztvevő pedagógusoktól évek óta gyüjti azokat a módszertani ötleteket, melyeket jól alkalmazhatónak tartanak az újonnan tanultakból. Elsősorban ezekből az ötletekből, gyakorlatokból épül fel a honlapon bárki számára elérhető Módszertani ötletgyújtemény ${ }^{3}$, melyet pedagógusok írnak kollegáik számára. A több mint 400 elemet tartalmazó adatbázist folyamatosan bővítjük, és minden pedagógusnak lehetősége van saját ötleteinek beküldésére. Az adatbázis több szempont alapján is kereshető (témakörök, korosztály, munkaforma, kulcskompetenciák és fejlesztendő készségek).

\section{Szakértői tanulmányutak az oktatási és képzési szakemberek számára}

Az oktatási és képzési kérdésekben való európai szintü információ- és tapasztalatcserét támogatja a Szakértői tanulmányutak alprogram, melynek keretében szakemberek vehetnek részt egyhetes tanulmányúton. A programban - elődprogramjaihoz hasonlóan - évtizedek óta eredményesen alkalmazzák azokat a tartalmakat (jó gyakorlatok) és munkaformákat (egymástól tanulás), melyek a nyitott koordináció elvének megfelelóen kulcsfontosságúak.

A kifejezetten gyakorlatias megközelítésü tanulmányúton 10-12 fő vehet részt, és elöadások meghallgatása mellett lehetöségük nyílik a különböző helyi, vagy

\footnotetext{
${ }^{3}$ Lásd: www.tka.hu $\gg$ Tudásközpont $>>$ Módszertani ötletgyüjtemény
} 
nemzeti szintű kezdeményezések gyakorlatban való tanulmányozására is, majd a tapasztalatok közös szakmai vitában való értékelésére. A témaköröket, melyek közt a hagyományosnak tekinthető oktatási témák mellett kifejezetten innovatív megközelítések is szerepet kapnak, úgy állította össze az Európai Bizottság, hogy hosszú távon is szolgálni tudja az Európai Unió oktatási és képzési rendszerekkel kapcsolatos céljait. Ez a hagyományostól eltérő ismeretszerzési forma - a visszajelzések alapján - valóban intenzív tanulást tesz lehetővé, miközben észrevétlenül fejleszti a szakértők személyes, szociális, szakmai kompetenciáit és persze nyelvtudását is. A résztvevők rendszerint számos, a saját és intézményi szakmai munkájukban hasznosítható ötlettel, jó gyakorlattal térnek haza, de egyben megteremtheti a hosszú távú nemzetközi szakmai kapcsolatok alapjait is.

A szakértői tanulmányutak keretében évente 50-70 fő kiutazásának támogatására van lehetőség.

\section{Mobilitási lehetőségek a pedagógusképzők számára}

Az Erasmus program a felsőoktatási intézmények bármely szakterületén tevékenykedő oktatói számára is kínál lehetőséget külföldi tapasztalatcserére néhány napos tanulmányi út keretében, így a pedagógusképzésben dolgozók is élhetnek a lehetőséggel. A programnak köszönhetően nemcsak a Magyarországról kiutazó oktatók profitálnak az útból, de a tanárképzési intézmények számára is komoly fejlődési lehetőséget jelent tapasztalt külföldi oktatók, szakemberek fogadása egy-egy kurzus erejéig. Ezzel egyúttal képzési program kínálatukat is gazdagíthatják, és azok a hallgatók is szerezhetnek nemzetközi tapasztalatot, akiknek nincs lehetőségük külföldre utazni.

Évente kb. 70 oktató veszi igénybe ezt a lehetőséget a pedagógusképzésben dolgozók közül. Az egyetemek, főiskolák nemzetközi együttmüködésére más lehetőségek is rendelkezésre állnak, de erre vonatkozóan nincs adatunk.

\section{Mobilitás pedagógia - tanártovábbképzés}

A Tempus Közalapítvány az európai mobilitási programok koordináló intézményeként az elmúlt 15 évben jelentős tudást halmozott fel a pályáztatás, bírálás, monitoring látogatások során, továbbá a beérkező pályázatok szakmai tartalmának feldolgozásával. Nemzeti irodaként a több ezer projekt áttekintéséből világos lett, hogy a mobilitás több mint egyéni kiutazások, tapasztalatszerzések összessége, kirajzolódott egy átfogó kép arról, hogy a mobilitás hogyan válhat egy komplex pedagógiai eszközzé, egy intézmény stratégiájának részévé.

Egyértelművé vált számunkra, hogy ennek a tudásnak a visszaforgatásával tudjuk legjobban elöre mozdítani a hazai mobilitási hajlandóságot. Ezért a Közalapitvány közel tíz éve képzöintézményként is müködik, képzéseit folyamatosan frissí- 
ti, újabbakkal bővíti. 2009 őszén megkezdtük egy mobilitás témájú pedagógustovábbképzési program kidolgozását.

A mobilitás történetére, típusaira, más tanulási formákhoz képesti sajátosságaira is kitérő elméleti háttérismeretek átadása mellett, a képzés elsősorban gyakorlatorientált, módszertanában kiemelt szerepet kap az interaktivitás. Egyes mobilitási projektek színvonalas megvalósítása rendkívül összetett folyamatszervezést igényel a megvalósítóktól: tervezés, forrásteremtés, projekt előkészítés, résztvevők előzetes felkészítése, külföldi tevékenységek megtervezése, lebonyolítása, partnerkapcsolatok ápolása, utókövetés stb. Ezért a kurzus elsődleges célja, hogy a résztvevők a mobilitási programok minden eleméhez esettanulmányokon, példákon keresztül ismerjenek meg a gyakorlatban is jól használható módszertani eszközöket.

Elképzelésünk szerint a képzésen való részvétel további hozadéka hogy tudatosítsuk a résztvevő pedagógusokban a mobilitási tevékenységekben rejlő intézményfejlesztési lehetőségeket. Néhány európai országban bevált gyakorlat a mobilitásra vonatkozó intézményi stratégia kidolgozása, melynek segítségével újra lehet gondolni a közös célokat, a rendelkezésre álló eszközöket, és valószínűsíthetö, hogy ebből nyilvánvalóvá válik mind a vezetők, mind a munkatársak számára, hogy hányan és milyen módokon profitálhatnak a rendszeres mobilitási programokból.

\section{Szakmai és regionális múhelymunkák, partnerség-építés}

A Tempus Közalapítvány jelentős szerepet vállal az európai szakmapolitikai együttmüködések eredményeinek hazai terjesztésében is, különböző témákban és programokon keresztül. Ennek érdekében intenzív kapcsolatot tart fenn a nemzetközi együttműködésekben résztvevő hazai szakértőkkel és döntés előkészítőkkel, aktív előre mozdítója a szakmai szereplők közti tudásmegosztásnak és különböző fórumokat müködtet az információk közzétételére (mühelymunkák, hírlevelek, tematikus honlap, szakértői fórum, kiadványok).

2008 óta egyre több olyan téma kerül az intézmény gondozásába, mely a pedagógusok szakmai felkészülését, tudásuk frissítését szolgálja. Ezek közül néhány kiemelt fontosságú:

- a kulcskompetenciák fejlesztése az alapfokú oktatásban;

- tanári kompetenciák, a tanárképzés európai megújulása;

- iskolavezetői kompetencia sztenderdek kidolgozása nemzetközi együttmüködésben.

Nagy hangsúlyt fektetve a gyakorlatorientált megközelítésre, igyekszünk az egyes témák kibontása során olyan programokat is kidolgozni, melyek közvetlenül a tanároknak szólnak. Ennek keretében az elmúlt másfél év során „Aktuális ürügyeink 
az együttműködésre - A kulcskompetenciák fejlesztésének támogatása” címmel hét regionális mühelymunkát szerveztünk az országban pedagógusok részére, mely a napi munkájukhoz nyújtott módszertani és szemléletbeli segítséget. Az egynapos tréning során a gyakorlati megközelítésű előadások, a helyi iskolai jó gyakorlatok bemutatása és a módszertani mini-tréningek mellett a résztvevőknek lehetőségük volt személyes véleményük, tapasztalataik, saját jó gyakorlataik megosztására is. Ezek a regionális rendezvények szorosan összefonódnak azzal a célkitüzéssel, hogy feltérképezzünk és összegyüjtsünk jó gyakorlatokat, módszereket, hasznos információkat a kompetencia alapú oktatás témájában és ezeket információs felületünkön közzétéve hozzájáruljunk az oktatási-nevelési kultúra fejlődéséhez, az iskolai hálózatok kiépüléséhez. Ezt a célt szolgálja a 2010 őszre tervezett rendezvénysorozatunk is, melyben a szülöket szólítjuk majd meg.

A hálózatosodás és partnerség-építés támogatása több más projektünknek is része. Szintén regionális mühelymunkákat szervezünk az egész életen át tartó tanulásban való együttmüködések támogatására, melyhez a honlapon elérhető partnerkereső adatbázist is fejlesztettünk. Ebbe bármilyen projektötlettel regisztrálhatnak oktatási és képző intézmények, civil szervezetek, cégek, érdekképviseletek stb., és saját adatlapjukon megjelölhetik, hogy milyen együttmüködésre keresnek partnert. $\mathrm{Az}$ adatbázis több szempont alapján is lekérdezhető (intézménytípus, régió) és lehetöség van szabad szavas keresésre is ${ }^{5}$.

\section{Disszemináció: projektbemutatók, tanulmányok, elemzések, konferenciák}

A programok láthatóvá válását, jelentőségük érzékelhetőségét a néhány évvel ezelött HOPPÁ Disszeminációs füzetek címmel indított kiadványsorozaton keresztül is támogatjuk. Bemutatjuk egy-egy projekt létrejöttét, eredményeit, és hatásait az adott intézményben. Bízunk benne, hogy a létrejövő projekteredmények más iskolák, pedagógusok számára is hasznosíthatók, ötletadók és ösztönzők lehetnek, akár a szakmapolitikai célok meghatározásához is.

A füzetek, valamint a hasonló célt szolgáló, félévenként megjelenő Pályázati Pavilon címủ magazinunk elektronikus formában is letölthetők a Közalapítvány honlapjáról: www.tka.hu >> Könyvtár.

\section{Következtetések}

Magyarországon van még bőven tennivaló a tanulási célú mobilitás előmozdítása területén, ugyanakkor az is elmondható, hogy a különböző programokban résztve-

\footnotetext{
${ }^{4}$ Lásd: www.oktataskepzes.hu >> Oktatás és képzés 2010 >> Az egész életen át tartó tanulást szolgáló kulcskompetenciák $>>$ Mühelymunkák

${ }^{5}$ www.oktataskepzes.tka.hu $\gg$ Az egész életen át tartó tanulás stratégiája $\gg$ Partnerség- és LLL hálózatépítés 2009-2010 >> Partnerkereső
} 
vők száma évről évre növekvő tendenciát mutat, és szerencsére ez igaz a tanári mobilitásokra is. Ugyanakkor - mint az más fejlesztések esetében is kimutatható -, a mobilitási programokon is csak az iskoláknak és tanároknak egy szükebb, szemléletében nyitottabb köre vesz részt rendszeresen. Akik élnek a lehetőséggel, azok egyöntetűen olyan szakmai fejlődési lehetőségről számolnak be, mely hagyományos körülmények között nem megteremthető. Ennek egyik lényegi eleme bizonyára az aktív cselekvésre épülö, éles gyakorlati helyzetekben való feladatmegoldás és megfelelés, mely a kapcsolódó pozitív érzelmi hatásokkal együtt egyszerre erősíti az önbizalmat és a motivációt. Másik fontos eleme pedig a szokásos tanítási szituációknál fokozottabban jelenlévő együttmüködésre utaltság lehet, mind a tanítványokkal, mind a kollegákkal. Az ilyen módon szerzett tapasztalatok - különösen, ha feldolgozásuk tudatosan megtörténik - beépíthetők a szakmai eszköztárba.

Több hivatalos európai dokumentum is említést tesz a tanári mobilitási lehetöségek támogatásának fontosságáról, így érdemes volna ezt itthon is jobban a figyelem középpontjába állítani, akár olyan kérdések átgondolásakor is, mint a tanári kompetencia sztenderdek megfogalmazása, hiszen a tanári pálya önmagában is egy egész életen át tartó tanulási program újabb és újabb kihívásokkal.

\section{Irodalom}

Az Európai Parlament és a Tanács ajánlása (2006. december 18.) a Közösségen belüli, oktatási és képzési célú transznacionális mobilitásról: az európai mobilitásminőségi charta (2006/961/EK) http://eur-lex.europa.eu/LexUriServ/site/hu/oj/2006/1_394/1_39420061230hu00050009.pdf

A Tanács és a tagállamok kormányainak a 2008. november 21-i Tanács keretében ülésező képviselői által elfogadott következtetések a fiatalok mobilitásáról (2008/C 320/03) http://eurlex.europa.eu/LexUriServ/LexUriServ.do?uri=OJ:C:2008:320:0006:0009:HU: PDF

A bolognai folyamat 2020 - Az Európai Felsőoktatási Térség az új évtizedben. Európa felsőoktatásért felelős minisztereinek nyilatkozata. Leuven és Louvain-la-Neuve, 2009. április 28-29.

magyarul: http://www.tpf.hu/upload/docs/bologna2/leuven_hu_2009_04_kn.pdf eredeti: The Bologna Process 2020 - The European Higher Education Area in the new decade

http://www.ond.vlaanderen.be/hogeronderwijs/bologna/conference/documents/Leuven Louvain-la-Neuve_Communiqué_April_2009.pdf

A Tanács következtetései (2009. május 12.) az oktatás és képzés terén folytatott európai együttmüködés stratégiai keretrendszeréröl („Oktatás és képzés 2020”) (2009/C 119/02) http://eur-lex.europa.eu/LexUriServ/site/hu/oj/2006/1_394/1_39420061230hu00050009.pdf

Zöld könyv a fiatalok tanulási mobilitásának elömozdításáról. Brüsszel, COM (2009) 209. http://ec.europa.eu/education/lifelong-learning-policy/doc/mobility/com329_hu.pdf

www.tka.hu, www.oktataskepzes.tka.hu 